Natalia Woroszylska

Stowarzyszenie Pisarzy Polskich, Warszawa

iD

ORCID https://orcid.org/0000-0003-1694-7613

\title{
UNIWERSYTET DOMOWY
}

- Woroszylska będzie miała piątkę - powiedziała po pierwszej wywiadówce w liceum moja wychowawczyni i nauczycielka rosyjskiego, Larysa Fiodorowna Saracyn, do wicedyrektorki szkoły Anny Radziwiłł'.

— Jak to!? — zdziwiła się Radziwiłł - a jeśli nie będzie umiała na piątkę?

- Ale jej tata tak pięknie mówi po rosyjsku! — wyjaśniła Larysa Fiodorowna.

Ta anegdota dobrze ilustruje zarówno oczekiwania otoczenia wobec mnie, jak i bezwyjściowość mojej sytuacji. No bo skoro tata...

Kiedy próbuję sobie przypomnieć, od czego się zaczęło, widzę obrazek ze szkoły podstawowej. Musiała to być czwarta klasa albo początek piątej, kiedy wprowadzano obowiązkową wówczas naukę języka rosyjskiego. Na przerwie przychodziły starsze dziewczynki i zadawały mi różne słowa do napisania po rosyjsku na tablicy. Widać rozeszła się fama, że jest taka uczennica, która umie pisać po rosyjsku, choć jeszcze się go nie uczy. Słowa zresztą były polskie, bo wprawdzie znałam rosyjskie litery, ale o ortografii i gramatyce nic nie wiedziałam, a zasób słów miałam ograniczony. Alfabetu nauczył mnie tata. Była to taka nasza wspólna zabawa.

\footnotetext{
${ }^{1}$ Anna Radziwiłł (1939-2009) - pedagog, historyk, autorka podręczników, uczestniczka obrad Okrągłego Stołu, wiceminister edukacji w latach 1989-1992 i 2004-2005.
} 
W szkole podstawowej nauczycielki zmieniały się często, ale wszystkie, na które trafiłam, czegoś mnie nauczyły. Kiedy znalazłam się już w liceum i nasza wychowawczyni, wspomniana Larysa Saracyn, na pierwszej lekcji zaczęła do nas mówić po rosyjsku (sama słabo wtedy znała polski), byłam chyba jedną z nielicznych - jeśli nie jedyną osobą - która rozumiała, co się dzieje na lekcji.

To właśnie Larysa Saracyn zmusiła mnie do poważnej nauki rosyjskiego. Okazało się, że jednak nie wystarczy, iż tatuś mówi po rosyjsku, trzeba było na tę piątkę mocno zapracować. Wypchnięta przez nauczycielkę na Olimpiadę Języka Rosyjskiego, zostałam finalistką i dostałam prawo wstępu bez egzaminów na studia rusycystyczne, z czego skwapliwie w odpowiednim czasie skorzystałam.

Szkoła dała mi wiele, ale istotniejsze bodaj było zaplecze domowe. Wspomniałam już o nauce liter, najważniejsze jednak było osłuchanie się z językiem rosyjskim, zapoznanie się z tematem rosyjskim. Przez nasz dom czasem przewijali się Rosjanie lub ludzie mówiący po rosyjsku. W rozmowie z Joanną Szczęsną na temat swoich związków z Rosją ojciec wspominał:

[...] w latach 60. i 70. zdarzało się, że przyjeżdżali do Warszawy Rosjanie, znajomi albo znajomi znajomych. Zwykle uprzedzano ich w ambasadzie sowieckiej: - Tylko pamiętajcie, nie wolno wam się stykać z Woroszylskim. Jednak niektórzy z nich pod przykryciem mroku odwiedzali mnie i byli szalenie dumni, że są tacy odważni. Później, już za czasów pieriestrojki, przyjeżdżali ludzie, którzy nie musieli być tacy odważni. Nie dźwigali tego całego bagażu strachu, tęsknoty za czymś, co musieli ukrywać... ${ }^{2}$

Z kolei w Dziennikach Wiktor Woroszylski odnotowuje późniejszą sytuację (z 29 sierpnia 1984 roku). Spotkany w autobusie znajomy dzieli się informacjami:

Jeszcze jedna wiadomość od niego: podobno zaproszono Jewtuszenkę na Warszawską Jesień Poezji i miał przyjechać, ale zapytany w związku z tym przez naczalstwo, czy spotka się z Woroszylskim, oświadczył, że oczywiście tak, i w rezultacie został wycofany $\mathrm{z}$ delegacji ${ }^{3}$.

${ }^{2}$ Ja $w$ Rosji, Rosja we mnie. Wiktor Woroszylski w rozmowie z Joanna Szczęsna, „Gazeta Wyborcza”, 6-8.04.1996.

${ }^{3}$ Wiktor Woroszylski, Dzienniki, t. 2, Warszawa 2018, s. 265. 
Jewtuszenko był u nas w domu jeszcze w latach 70., tego samego wieczora miał mieć występ w Teatrze Powszechnym. Zapamiętałam to zdarzenie. Poeta, rozochocony spotkaniem przy stole, zupełnie nie chciał opuścić towarzystwa. Dzwoniono do nas z teatru, publiczność już czekała, a on nic sobie z tego nie robił. Wreszcie udało się odciągnąć go od stołu, a ja dostałam zadanie odprowadzenia Jewgienija Aleksandrowicza do taksówki i dopilnowania, żeby do niej wsiadł. Na moje szczęście wszystko pomyślnie się skończyło. Publiczność się doczekała - a były wśród oczekujących moje wspomniane już profesorki z liceum, które przepytywały mnie później, co się stało z Jewtuszenką. Byłam na tym występie innego dnia i wtedy po raz pierwszy zetknęłam się ze śpiewną rosyjską deklamacją ${ }^{4}$.

Pamiętam też spotkanie na cześć innego rosyjskiego poety, Bułata Okudżawy. Moją pamięć wspierało przez lata nagranie jego koncertu u nas w domu. Woroszylski wspomina ten koncert, a także okoliczności swojej znajomości z Okudżawą w nocie o poecie pomieszczonej w antologii Moi Moskale:

Poznałem Bułata podczas któregoś z jego pobytów w Warszawie w latach sześćdziesiątych, wtedy też powstały pierwsze moje tłumaczenia, a w grudniu 1970 roku odbył się niezapomniany koncert w naszym mieszkaniu na Żoliborzu - dla kilkudziesięciu przyjaciół: literatów, aktorów STS-u, świeżo wypuszczonych z pomarcowych więzień studentów [...]. Na taśmie [...] zachował się młody głos Okudżawy, chóralny śmiech przy piosence o panu Gąsce, w przerwach gwar i fragmenty rozmów... Chyba wtedy, oraz parę dni później podczas wyprawy w Góry Świętokrzyskie, do leśniczostwa Zielińskich, pękły między nami (obydwoma jakoś tam nieśmiałymi) ostatnie lody. A wiesz — powiedział Bułat, kiedy odwiedziłem go w Moskwie w sierpniu 1994 roku — że to trzydziestolecie naszej znajomości?...5

${ }^{4}$ Zabawny szczegół z wizyty Jewtuszenki odnotowany jest też w cytowanej rozmowie z Joanną Szczęsną: „Byłaś u nas w 1975 roku na przyjęciu dla Jewtuszenki, kiedy zawołał mnie do kuchni i zapytał: - A kto tu z obecnych jest...? I zastukał zgiętym palcem we framugę, bo w Rosji donosiciel to 'stukacz'. Kiedy mu powiedziałem, że nikt, uznał mnie za naiwnego. To mu się wydawało niemożliwe, ktoś musiał być". Opisana sytuacja utrwalona została w wierszu Wiktora Woroszylskiego Młodzi Rosjanie 1989.

${ }^{5}$ W. Woroszylski, Moi Moskale, Biuro Literackie, Wrocław 2006, s. 392. 
Pamiętam nie tylko ten koncert (na nagraniu słychać też było poszczekiwanie naszego psa Kluchy i głos ojca, mitygującego przyjaciela: „Rysiu, nie drażnij psa”), ale i wyprawę dwoma samochodami w Góry Świętokrzyskie, i o wiele późniejsze spotkanie w Moskwie, gdzie wówczas mieszkałam, ale o tym za chwilę.

Rosję i Rosjan poznawałam także poza domem. Dość wspomnieć o podróży nie do Rosji, co prawda, ale do nierosyjskiej części ZSRR - do Grodna, Wilna i Tallina. To wtedy odbyły się dwa pamiętne dla mnie spotkania. Jedno z nich, z Josifem Brodskim, zostało opisane zarówno przez mojego ojca w tekście Trzy fotografie, jak i przez naszego wileńskiego gospodarza, litewskiego poetę Tomasa Venclovę, z którego inicjatywy do niego doszło. Moja obecność przydała się do opisu tej sytuacji wiele lat później:

Dokładną datę zawdzięczam prowadzonemu w podróży dzienniczkowi naszej trzynastoletniej wówczas córki Natalii. [...] A więc 5 kwietnia 1971. Był to długi dzień - tak długi, że i ja sam, i Tomas, zapamiętaliśmy go nie jako jeden, ale kilka gęsto wypełnionych dni. [...] W rzeczywistości — dzienniczek Natalii jest tu najbardziej wiarygodnym świadkiem! - Josif zjawił się w Wilnie w poniedziałek przed południem, a we wtorek o tej samej mniej więcej porze, ja z żoną i córką wyjechaliśmy do Grodna ${ }^{6}$.

Mój dzienniczek pozwolił także odtworzyć niektóre, może i nie najważniejsze, ale barwne, szczegóły dnia, na przykład:

Tam [w Trokach] w gospodzie zjedliśmy obiad i nie uchybię, mam nadzieję, celowi, dla którego spisuję tę relację, odnotowując za kronikarką, że głównym daniem były pierożki karaimskie z baranim farszem, cebulą i pieprzem ${ }^{7}$.

Wsparciem dla pamięci ojca były też tytułowe trzy fotografie. Ta najbardziej znana, wielokrotnie publikowana ${ }^{8}$, przedstawia trzech poetów na moście na jeziorze w Trokach. Z kolei moją pamięć ożywia fotografia, która uchwyciła od tyłu sylwetki na murze zamko-

\footnotetext{
${ }^{6}$ Tegoż, Trzy fotografie, w: P. Fast (red.), O Brodskim. Studia - szkice - refleksje, „Śląsk”, Katowice 1993, s. 15-16.

${ }^{7}$ Tamże, s. 19.

${ }^{8}$ Fotografia była ilustracją cytowanego wspomnienia Trzy fotografie, wywiadu Ja w Rosji, Rosja we mnie, ukazała się w Dziennikach, krąży także w internecie.
} 
wym. Przodem idzie Venclova, dalej Brodski, na końcu ja, w czerwonym (ale tego na czarno-białym zdjęciu nie widać) kapelusiku i płaszczyku midi, za którym wszyscy się oglądali - moda midi ledwo się zaczynała. Patrząc na to zdjęcie, słyszę dobiegający mnie głos Brodskiego, recytującego po polsku Zaczarowana dorożkę Konstantego I. Gałczyńskiego.

Drugie wyjątkowe spotkanie w czasie tamtej podróży nastąpiło w Tallinie. Odtworzyłam je wiele lat później na łamach „Nowej Polszy":

Kiedy zobaczyłam Gennadija Ajgiego po raz pierwszy, miałam 13 lat. To było bardzo niezwykłe spotkanie dla wszystkich jego uczestników. A ja jestem szczególnie dumna, ponieważ dwa lata później Gennadij Ajgi przysłał zadedykowany mi wiersz Lekcje polskiego. Nie ma przecież na świecie wielu dziewczynek, którym wielcy poeci poświęcili wiersze 9 .

Dalej opisałam sam moment spotkania. Ajgi przyjechał pod naszą nieobecność.

Pamiętam to spotkanie na schodach. Weszliśmy do klatki schodowej i napotkaliśmy brodatego człowieka niskiego wzrostu, o lekko skośnych oczach. Ojciec i ten pan przez dłuższą chwilę wpatrywali się w siebie, jakby szukając znajomych rysów, niepewnie wypowiedzieli swoje imiona, po czym rzucili się sobie w ramiona. Poczułam wtedy, że między nimi - moim ojcem i Ajgim jest jakaś niezwykła więź ${ }^{10}$.

O tej niezwykłej przyjaźni, przez długi czas właściwie zaocznej, ojciec pisał:

...korespondowaliśmy ze sobą, wysyłaliśmy sobie (korzystając z pośrednictwa życzliwych podróżników) wiersze, książki, a nawet obrazy, ale pomiędzy naszym pożegnaniem w Moskwie w roku 1956, a następnym spotkaniem „na żywo" upłynęło piętnaście lat, do jeszcze następnego miało upłynąć kolejnych

${ }^{9} \mathrm{Z}$ archiwum autorki. Tekst opublikowano po rosyjsku: Н. Ворошильская, Встречи с Айги, „Новая Польша” 2006, nr 4, s. 51-52. Jego fragmenty były wykorzystane w relacji z wystawy w Moskwie w 2019 roku poświęconej Ajgiemu i opublikowane w „Zeszytach Literackich”, https://www.zeszytyliterackie.pl/ natalia-woroszylka-jeszcze-jedno-spotkanie-z-gennadijem-ajgim/(16.08.2020).

${ }^{10}$ Tamże. 
lat dziewiętnaście. A jednak było to prawdziwe obcowanie, współpraca i po$\operatorname{moc}^{11}$.

Ja także woziłam w obie strony rozmaite przesyłki poetów - listy, książki, materiały do pracy, upominki. W okresie mego późniejszego dłuższego pobytu w Moskwie rodzina Ajgiego stała się rodziną i dla mnie. Właśnie z Ajgim przeprowadziłam swój pierwszy wywiad $^{12}$.

Rosja, którą poznawałam dzięki ojcu, była także w Paryżu. To właśnie tam zdarzało mi się bywać zwłaszcza w okresie studiów. Odwiedzałam emigracyjną księgarnię rosyjską na rue de la Montagne Sainte-Geneviève, w której miałam prawo grzebania na zapleczu i dostawałam książki dla ojca. Próba ich przywiezienia pewnego razu skończyła się dla mnie rewizją na Okęciu i odebraniem wszystkiego ${ }^{13}$.

Jedną z osób spotkanych w Paryżu była Natalia Gorbaniewska, która - zaledwie kilka miesięcy wcześniej zmuszona do emigracji - dopiero co osiedliła się w stolicy Francji. Pisałam o tym we wspomnieniu po jej śmierci:

Poznałam ją, jak to sobie teraz uświadamiam, kiedy była młodą, 40-letnią kobietą. Ale tak wówczas o niej nie myślałam. Sama nie miałam jeszcze dwudziestu lat, no i wiedziałam, jakie przejścia Gorbaniewska ma już za sobą. W 1976 roku przyjechałam z rodzicami do Paryża. Po ich wyjeździe zostałam na pierwsze swoje samodzielne zagraniczne wakacje. Spotkałam się z Nataszą któregoś wieczora i zabrała mnie na cudowny spacer po dzielnicy łacińskiej. Muzykanci uliczni, przedstawienia marionetkowe na ulicy, gwar i światła. Zaglądałyśmy do pubów, tabaców i wszelkich miejsc, gdzie były czynne stoiska z zegarkami. Natalia chciała kupić prezent na urodziny swojego syna Jasika. Nie wiem, czy dostał wówczas zegarek, bo tego wieczora żaden jej się nie spodobał. Wielokrotnie jeszcze z Nataszą spacerowałam, ale tamten spacer

\footnotetext{
${ }^{11}$ W. Woroszylski, Moi Moskale..., s. 401.

${ }^{12}$ Wywiad był drukowany w prasie polskiej i rosyjskiej, ukazał się też w książce: Gennadij Ajgi, Tutaj. Eseje i wiersze, przeł. W. Woroszylski, Fundacje Pogranicze, Sejny 1995.

${ }^{13}$ Jak traumatyczne było to przeżycie, przypomniałam sobie, czytając zapis w Dziennikach ojca. Zob. W. Woroszylski, Dzienniki, t. 1, Ośrodek Karta, Warszawa 2017, s. 259-260.
} 
najbardziej utkwił mi w pamięci — nigdy nie widziałam kogoś tak łapczywie chłonącego wolnośćc ${ }^{14}$.

Mogłabym mnożyć nazwiska i opowieści. Tych kilka anegdot wystarczy jednak, żeby pokazać, że dostałam Rosję w jej całej różnorodności i złożoności. Od najmłodszych lat wiedziałam, że oprócz tej oficjalnej jest Rosja wolna, Rosja ciekawych i nadzwyczajnych ludzi, że nie każdy człowiek mówiący po rosyjsku jest Rosjaninem, że Rosja i ZSRR to nie to samo. Nie było to powszechne w moim pokoleniu. Nie raz słyszałam, że rosyjskiego trzeba się uczyć, żeby poznać język wroga, albo - że z tego właśnie powodu - trzeba się go nie uczyć. To mi nigdy nie przychodziło do głowy, kiedy później zostałam nauczycielką rosyjskiego.

Zanim to się stało, znalazłam się na studiach rusycystycznych. Miałam przecież prawo wstępu bez egzaminów właśnie na rusycystykę i innych możliwości w ogóle nie brałam pod uwagę. Nie skorzystałam z porad rodziców, zwłaszcza żartobliwych nacisków ojca, że może by raczej pójść na matematykę. W odróżnieniu ode mnie wiedział, jak trudno mi będzie radzić sobie z ciężarem dorobku ojca, jeśli będę działać w tej samej dziedzinie, a zarazem jak kiepskie były perspektywy zawodowe dla filologa rusycysty w tamtych czasach.

Okres moich studiów przypadł na koniec lat 70., a więc czas bujnego rozkwitu drugiego obiegu i kultury niezależnej. Na wydziale za bardzo się tego nie czuło. Co innego w domu: w roku akademickim 1978/1979 w naszym mieszkaniu ojciec prowadził, w ramach Towarzystwa Kursów Naukowych, cykl wykładów o literaturze rosyjskiej ${ }^{15}$. Niektórzy moi znajomi z uczelni byli ich słuchaczami ${ }^{16}$.

${ }^{14}$ N. Woroszylska, Dom Nataszy na Żoliborzu. Wspomnienie o Natalii Gorbaniewskiej wygłoszone podczas Dni Pamięci Natalii Gorbaniewskiej we Wrocławiu w 2014 r. Z archiwum autorki.

${ }^{15}$ W. Woroszylski, Wykłady o literaturze rosyjskiej (Uniwersytet Latający 19781979), przygotował do druku P. Mitzner, Wydawnictwo Naukowe UKSW, Warszawa 2020.

${ }^{16}$ Zdarzyła się też przykra sytuacja. Jedna ze studentek rusycystyki, działaczka SZSP, starościna mojego roku — Grażyna Zadykowicz — znalazła się w naszym domu w zgoła innej roli. Na ostatnie zajęcia, 26 kwietnia 1979 roku, przyszła 
Wśród wykładowców miałam szczęście spotkać kilka wspaniałych osób z doktor Jadwigą Wajszczuk na czele, która zaangażowała mnie w działalność studenckiego koła naukowego. Praca w kole naukowym bardzo mi się spodobała, ale nie myślałam o karierze naukowej, zresztą było oczywiste, że dla córki Woroszylskiego ta droga jest zamknięta. Pracę magisterską obroniłam 30 września 1980 roku, miesiąc po podpisaniu porozumień sierpniowych. To był moment, kiedy wydawało się, że nawet na tym skostniałym wydziale coś się zmienia. Pojawiła się myśl, że jednak mogłabym zająć się pracą naukową. Miałam dyplom z wyróżnieniem, świetną opinię od opiekunek koła naukowego. Udałam się do mojego promotora, profesora René Śliwowskiego, który obiecał poprzeć moje starania o przyjęcie na staż, ale nie robił wielkich nadziei: „Wie pani, ambasada radziecka patrzy nam na ręce.... Z kolei profesor Antoni Semczuk, ówczesny dyrektor Instytutu Rusycystyki, wyraził zdziwienie: „Ale dlaczego dopiero teraz pani przychodzi, tak późno?”. Odpowiedziałam bez owijania w bawełnę, że przecież do niedawna nie było to możliwe. „Ależ nie demonizujmy” — powiedział profesor, a na staż przyjęto jego magistrantkę.

Nie pamiętałabym o tym, bo z dzisiejszej perspektywy wydaje mi się, że był to zaledwie incydent. Jednak drobny jego ślad, który odnalazłam niedawno w korespondencji rodzinnej, przypomniał mi, że boje o mnie trwały jeszcze kilka miesięcy. Kiedy w Warszawie się nie udało, podejmowano próby w innych ośrodkach uniwersyteckich. Ale karnawał wolności trwał krótko. Wszystko wskazywało na to, że sprawa będzie pomyślnie rozwiązana, że jest miejsce na krakowskiej rusycystyce, ale nagle zaczął się stan wojenny, mój ojciec został internowany ${ }^{17}$, a wraz $\mathrm{z}$ nim niektórzy z bojowników mojej sprawy. Z jednym z nich, profesorem Andrzejem Bogusławskim, ojciec zapoznał się w ośrodku internowania w Jaworzu. W li-

wraz z ok. 20-osobową grupą mężczyzn, którzy usiłowali zerwać wykład. Po ok. 1,5 godz. słownych przepychanek na sygnał jednego z nich wszyscy wyszli.

${ }^{17}$ Wiktor Woroszylski został internowany 13 grudnia 1981 roku, przebywał w ośrodkach internowania w Białołęce (13-22 grudnia 1981), Jaworzu (22 grudnia 1981 - 22 maja 1982) i Darłówku (22 maja - 18 października 1982). Był jednym z pisarzy najdłużej przetrzymywanych w internowaniu. 
ście stamtąd, kilka dni po przeniesieniu z Białołęki, opowiadając o rozkładzie zajęć i nowych kolegach, ojciec pisał:

Z wykładów, które nas jeszcze czekają, cieszę się na Bogusławskiego. Ten na odmianę opowiedział mi o perypetiach z asystenturą mojej Córki - doszliśmy do wspólnego wniosku na ich temat - i dorzucił, że „Natalia pod wszelkimi względami stała o dwie klasy wyżej od całej reszty”, więc byłem dumny jak paw, bo słuchali tego i inni ${ }^{18}$.

I tak oto nie zrobiłam kariery naukowej.

Rozpoczęłam jednak pracę nauczycielską i w 1981 roku znalazłam się w moim dawnym liceum, gdzie przepracowałam wprawdzie tylko rok, ale za to u boku szanowanych przeze mnie nauczycielek, od których teraz uczyłam się nie historii czy rosyjskiego, ale zawodu. Nauczycielstwo bardzo mi się spodobało, odkryłam w sobie powołanie. Okazało się, że te same wydarzenia, które zniweczyły moją karierę naukową, wpłynęły także na ledwie się zaczynającą karierę nauczycielską. Kuratorium nie przedłużyło ze mną umowy z powodu rzekomego braku godzin. „Zabrakło” ich także w kilku innych szkołach. W liście z Darłówka do mnie i mamy ojciec pisał:

[...] martwię się [...] straceniem pracy przez Natalijkę. Starania szkoły etc. o odkręcenie tego są krzepiące, ale Pan Bóg raczy wiedzieć, czy dadzą skutek. Jeżeli kłopoty się przeciągną, myślę, Córeczko, że warto, żebyś się znowu bardziej zaczęła orientować na tłumaczenia, do których nie od dzisiaj Ciebie namawiam i w których zrobiłaś pewne postępy, ale - rzecz jasna - ograniczone przez zbytnią dorywczość, nieregularność tych zajęć. Ze szkołą, co prawda, mogło to być trudne do pogodzenia, natomiast w zmienionej sytuacji trzeba chyba spróbować. Piszę to, oczywiście, bez wszelkiego nacisku, sama wiesz najlepiej, co masz robić, po prostu myślę pisząc ${ }^{19}$.

Nieco później zaś, już w innej kartce do mnie, w trochę innym tonie dodawał:

[...] podobnie jak Ty nie przejmuję się zbytnio wyrzuceniem Ciebie z pracy — jest to ewidentne łajdactwo, ale byłem na nie przygotowany. Na razie odpo-

${ }^{18}$ Jaworze, 29.12.1981 r. Wszystkie cytowane listy Wiktora Woroszylskiego z ośrodków internowania znajdują się w archiwum autorki.

${ }^{19}$ Darłówko, 9.07.1982 r. 
czywaj w miarę możliwości, a potem rzecz będzie polegała na paru drobiazgach: żeby stworzyć sobie koncepcje tego, co chce się i może robić, żeby z pewną dozą energii wystarać się o jakieś formalne i materialne podstawy swoich zajęć, żeby narzucić sobie dyscyplinę i systematyczność ich uprawiania... ${ }^{20}$

W liście do mamy wraca niepokój:

O Natalię trapię się (to już drugie niepowodzenie, najpierw uniwersytet, teraz szkoła), a jednocześnie wierzę, że starczy jej uporu i hartu, żeby nie dać się wdeptać w ziemię. Przecież po nas obojgu odziedziczyła tzw. twardy charakter! ${ }^{21}$

Uporu i hartu starczyło mi, żeby zdecydować się na przyjęcie jedynej wtedy możliwej propozycji pracy w szkole. Była to szkoła podstawowa, a do moich obowiązków należało nauczanie rosyjskiego i... historii. Wytrwałam. Po dwóch latach udało się przenieść do liceum, w którym pracowałam dziewięć lat, doczekałam kolejnej wolności, byłam nawet przez kilka lat wicedyrektorem, a - co najważniejsze - czerpałam z tej pracy wiele przyjemności i satysfakcji. Adam Pomorski ${ }^{22}$ parę razy w sytuacjach towarzyskich żartował sobie, że jestem jedyną znaną mu osobą, która prowadziła tajne komplety $\mathrm{z}$ rosyjskiego. Przypomnę, że rosyjski był w PRL-u przedmiotem obowiązkowym, traktowanym ideologicznie, uczniowie $\mathrm{z}$ reguły nie garnęli się do nauki. Tajne komplety w rzeczywistości były konwersacjami dla chętnych, a żeby nie wypełniać stert biurokratycznej dokumentacji, prowadziłam je nieoficjalnie, społecznie - w domu, przy herbacie i ciasteczkach. Przez wiele lat spotkanie te cieszyły się zainteresowaniem kolejnych roczników.

W pracy tłumaczeniowej skazana więc byłam nadal na dorywczość, nieregularność, jednak podobała mi się ona. Wprawdzie ojciec, jak pisał w liście, nie naciskał, ale znajdował sposoby, aby mnie w nią angażować. Na przykład, pierwsze moje opublikowane tłumaczenia robiłam dla niego „na czarno”, kiedy jeszcze byłam

\footnotetext{
${ }^{20}$ Darłówko, 26.07.1982 r.

${ }^{21}$ Darłówko, 14.08.1982 r.

${ }^{22}$ Adam Pomorski (1956) - tłumacz, eseista, krytyk literacki, od 2010 roku prezes Polskiego PEN Clubu.
} 
licealistką. Były to drobne utwory Daniiła Charmsa dla dzieci, wydrukowane chyba w „Płomyczku”.

W późniejszych latach ojciec czasami wciągał mnie do współpracy. Razem pracowaliśmy nad tymże Charmsem, publikując nasze przekłady w prasie kulturalnej, a w końcu wydając książkę ${ }^{23}$. Wielkim wyzwaniem był Zoszczenko - tłumaczenie jego tekstów także zostało zwieńczone książką ${ }^{24}$. W pracy nad śpiewnikiem Wysockiego $^{25}$ uczestniczyłam głównie jako dostarczyciel nagrań, ale łagodna presja i wsparcie redaktorskie sprawiły, że spróbowałam także sił w przekładzie poetyckim ${ }^{26}$.

Okres stanu wojennego był czasem, kiedy zastępowałam ojca w niektórych jego innych zajęciach literackich. Otóż od wielu lat prowadził on rubrykę "album poezji miłosnej” w „Zwierciadle”, które było wówczas tygodnikiem. Od czasu, gdy Wiktor Woroszylski został objęty zakazem druku, rubryka ukazywała się bez podpisu. $\mathrm{Z}$ internowania tak pisał w tej sprawie:

À propos „Zwierciadła”, dowiedzcie się, czy nie zacznie ono znowu niebawem wychodzić. Jeżeli tak, powstaje kwestia mojej rubryki „album poezji miłosnej”. Niestety, stąd będzie mi ją nawet trudniej prowadzić, niż było w zeszłym roku z zagranicy [dłuższy pobyt na stypendium w Berlinie Zachodnim]. Nie chciałbym jednak, żeby znikła, ani żeby zaczął ją robić ktoś obcy. Najlepiej by było, Natalijko, żebyś Ty się tego podjęła, a ja bym Ci pomagał w listach pewnymi sugestiami i wskazówkami. Przejrzyj, proszę, trochę starych wycinków, a szybko złapiesz, o co chodzi ${ }^{27}$.

${ }^{23}$ D. Charms, Tygrys na ulicy, przeł. N. Woroszylska, W. Woroszylski, Wydawnictwo Verba, Chotomów 1991.

${ }^{24}$ M. Zoszczenko, Bądź człowiekiem, towarzyszu!, przeł. N. Woroszylska, W. Woroszylski, Wydawnictwo Marabut, Gdańsk 1993.

${ }^{25} \mathrm{~W}$. Wysocki, Głos gitary tłucze w mur. 30 piosenek na głos i gitare, wyb. i red. N. Woroszylska, W. Woroszylski, oprac. J. Butrym, Polskie Wydawnictwo Muzyczne, Kraków 1989.

${ }^{26}$ Nie po raz pierwszy. Nieco wcześniej dwa moje przekłady trafiły też do śpiewnika Okudżawy: B. Okudżawa, Nadziei amatorski zespót. 22 piosenki na głos i gitarę, przeł. W. Dąbrowski i in., Polskie Wydawnictwo Muzyczne, Kraków 1988.

${ }^{27}$ Jaworze, 31.01.1982 r. 
I rzeczywiście, w kolejnych listach dostawałam sugestie i wskazówki:

Natalijko, gratuluję Ci pierwszego pomyślnie wykonanego „albumu”. Dalej pójdzie łatwiej. Ważne jest, żebyś opanowała rozmiar, tzn. żeby każdy nie przekraczał stronicy maszynopisu (nie licząc wiersza). Z ostatnio zakupionych książek popatrz pod kątem wykorzystania w „albumie” na wybór wierszy irlandzkich i tom Stroińskiego ${ }^{28}$.

Porady i sugestie obejmowały całokształt spraw, związanych $\mathrm{z}$,albumem”:

Natalijko, czy pamiętałaś, co Ci sugerowałem, żeby poprosić w „Zwierciadle” o podwyższenie stawki? Dotychczasową ustalono ponad 10 lat temu ${ }^{29}$.

Niestety, do dziś nie opanowałam umiejętności negocjowana honorarium w dostatecznej mierze. Wtedy chodziło o honorarium ojca, bo w redakcji występowałam jako pośrednik i nikt nie wiedział, że to ja piszę kolejne odcinki. Nie pamiętam, czy się udało.

Czasem zdarzały mi się wpadki:

[...] albumy Twojego pióra w zasadzie podobają mi się, tylko jednego zdania o Osieckiej, skądinąd prawdziwego, raczej bym nie napisał: „chociaż autorka nie należy już do najmłodszej generacji poetów” - bo jak to przeczyta, nie będzie jej zbyt przyjemnie. Ach ta młodzieńcza szczerość $!^{30}$.

Wszystkie moje błędy szły przecież na konto ojca, ale nigdy nie miał o nie pretensji, wielokrotnie natomiast byłam obiektem żartów rodzinnych z powodu tego zdania.

[...] korzystam z okazji, Natalijko, żeby pochwalić kolejny „album” w „Zwierciadle" (Belleau) - mam wrażenie, że poruszasz się w tej rubryce coraz swobodniej, czasem tylko wydaje mi się niekonieczny jakiś przymiotnik („w świetnym przekładzie"), ale to drobiazg. Kiedy wrócę, nie zechcesz mi pewnie tej roboty odstąpicín ${ }^{31}$.

\footnotetext{
${ }^{28}$ Jaworze, 2.04.1982 r.

${ }^{29}$ Jaworze, 17.04.1982 r.

${ }^{30}$ Darłówko, 29.08.1982 r.

${ }^{31}$ Darłówko, 29.08.1982 r.
} 
Byłam przekonana, że zrobiłam może ze cztery „albumy”, ale z listów wynika, że prowadziłam tę rubrykę przez wiele miesięcy. Wbrew obawom ojca, po jego powrocie do domu oddałam mu ją bez szemrania i powróciłam do głównego zajęcia nauczycielskiego i dorywczego tłumaczenia. Z dzisiejszej perspektywy widzę, że ten „albumowy" trening pomógł mi bardzo w kolejnych moich profesjach.

W 1993 roku zdecydowałam się odejść ze szkoły i z nauczycielstwa, które do dziś uważam za swój najważniejszy zawód. Jednak nie dla tłumaczeń opuściłam szkołę, ale na rzecz przygody, która też była w jakimś sensie wariacją losu mojego ojca ${ }^{32}$. Otóż dostałam propozycję wyjazdu do Moskwy na cztery lata i objęcia stanowiska wicedyrektora Instytutu Polskiego (wtedy jeszcze Instytutu Kultury Polskiej). Jak pisałam z okazji 30-lecia placówki:

Początek mojej pracy w Instytucie Polskim w Moskwie można nazwać wybuchowym. Przyjechałam na początku października 1993, od dwóch tygodni trwał już kryzys polityczny. Nazajutrz po moim przyjeździe rozległy się strzały. Szturm Białego Domu — ówczesnej siedziby Parlamentu, oglądaliśmy wszyscy w telewizji i słyszeliśmy przez okna. Później żartowałam, że ten salut armatni to na moją cześćc ${ }^{33}$.

Pisząc o istocie mojej pracy w Moskwie, sformułowałam to nieco żartobliwie:

Nigdy wcześniej ani później nie prowadziłam aż tak ciekawego i intensywnego życia kulturalnego. I na dodatek wszystkie imprezy miałam pod bokiem (ale najpierw trzeba je było zaplanować, potem zorganizować i nadzorować) ${ }^{34}$.

Także w Moskwie dopadł mnie ciężar bycia córką znanego ojca. Któregoś dnia przeczytałam:

Na stanowisko dyrektora Instytutu w Moskwie wysunął [Bartoszewski] córkę Wiktora Woroszylskiego, która „zasłużyła” się głównie tym, że wiernie

32 Janina i Wiktor Woroszylscy byli na studiach doktoranckich w Moskwie w latach 1952-1956.

${ }^{33}$ N. Woroszylska, Moskiewska przygoda. Tekst opublikowany po rosyjsku w broszurze wydanej przez Instytut Polski w Moskwie z okazji 30-lecia. Moskwa 2018. Oryginał w archiwum autorki.

${ }^{34}$ Tamże. 
towarzyszyła na spacerach z pieskiem pani marszałkowej, żonie poprzedniego dyrektora, który zresztą samowolnie opuścił stanowisko ${ }^{35}$.

Spotykające mnie w życiu mniejsze i większe przykrości, które były konsekwencją nazwiska, przyjmowałam spokojnie. Skoro jestem z tej rodziny, to muszę i chcę dzielić z nią ciężary. Spotykały mnie także miłe sytuacje i ułatwienia. Je też uważałam za należne. Do dziś otwiera się przede mną wiele drzwi.

Ale wróćmy do Moskwy. Podtrzymywałam kontakty ze znajomymi i przyjaciółmi rodziców, niektóre $\mathrm{z}$ nich stały się moimi przyjaźniami, niektóre domy stały się moimi domami, jak dom Kseni Starosielskiej ${ }^{36}$. Tym razem powołam się właśnie na jej na słowa wypowiedziane $\mathrm{w}$ wywiadzie, który $\mathrm{z}$ nią przeprowadziłam zaraz po tym, jak w 2008 roku otrzymała najważniejszą polską nagrodę dla tłumaczy literatury polskiej „Transatlantyk”. Ksenia opowiadała o swoim pierwszym pobycie w Polsce w 1967 roku:

Pierwszy dom, do którego przyszłam w Warszawie, to był wasz dom. Zostałam tak ciepło przyjęta, otoczona taką miłością, że Janka i Wiktor Woroszylscy już na zawsze weszli w moje życie, i dlatego ciebie uważam po prostu za rodzinę ${ }^{37}$.

Jedną $\mathrm{z}$ moich moskiewskich przygód było radio. Najpierw byłam gościem na antenie Echa Moskwy - pierwszego niepaństwowego rosyjskiego radia, wówczas istniejącego zaledwie od trzech lat, ale już niezwykle popularnego. A potem, nieoczekiwanie dla samej siebie, zostałam jego współpracowniczką - zaproszono mnie do prowadzenia cyklicznej audycji o polskiej piosence. Wtedy jeszcze nie wiedziałam, że już wkrótce radio stanie się moim kolejnym zajęciem. Po powrocie do kraju trafiłam do redakcji rosyjskiej

\footnotetext{
${ }^{35}$ H. Schulz, Pierdoty spod cylindra, „Nie”, nr 15, 13.04.1995. Głównym obiektem ataku był dyrektor Instytutu Polskiego Rafał Marszałek, mnie dostało się rykoszetem.

${ }^{36}$ Ksenia Starosielska (1937-2017) - tłumaczka literatury polskiej.

${ }^{37}$ Wywiad emitowany na antenie Polskiego Radia dla Zagranicy, opublikowany w „Nowej Polszy”: Думать над каждым словом. Беседа с Ксенией Старосельской, „Новая Польша” 2008, nr 11, s. 42-47.
} 
Programu dla Zagranicy Polskiego Radia i kierowałam nią prawie przez 20 lat.

Niemal ćwierć wieku minęło od śmierci Wiktora Woroszylskiego, jednak poczucie, że nadal dzielę los rodziny, nie ustępuje. W wierszu Moje nowe zajęcie $e^{38}$ ojciec pisał o tym, jak coraz częściej inni zgłaszają się do niego po wspomnienia o odchodzących przyjaciołach. Teraz czasem znów go zastępuję. Kiedy żegnam przyjaciół, którzy byli też jego przyjaciółmi, staram się robić to także w imieniu ojca, szukam jego słów, rozproszonych po różnych tekstach. Moim nowym zajęciem stało się porządkowanie archiwum ojca i dbanie o jego spuściznę. Mam pewne osiągnięcia na tym polu, co odnotował niedawno Jacek Bocheński w Blogu III:

Autor [Wiktor Woroszylski] nie żyje, a są czytelnicy ogromnych Dzienników, o których edycję zadbała córka Natalia ${ }^{39}$.

Gdy chodzi o porządki w archiwum, ojciec sam wykonał istotną część tej pracy. A jednak brakuje mi wskazówek i sugestii w tej kwestii. Jak i w wielu innych. Pracą tłumaczeniową natomiast zajmuję się, jak zwykle, z doskoku i dorywczo.

Wiktor Woroszylski (1927-1996) - poeta, prozaik, eseista, autor książek dla dzieci i młodzieży, tłumacz i znawca literatury rosyjskiej. W młodości był komunistą, stał się liderem tzw. pokolenia pryszczatych. Pobyt w ZSRR (studia doktoranckie w Moskwie w latach 1952-1956) był początkiem odchodzenia od komunizmu, z kolei świadectwo powstania węgierskiego (1956) - jego przypieczętowaniem. W latach 60. należał do grona pisarzy coraz bardziej krytycznych wobec władz, wraz z grupą pisarzy wystąpił w obronie Leszka Kołakowskiego, usuniętego z PZPR-u, i sam następnie opuścił partię. W latach 70. i 80. stał się aktywnym uczestnikiem opozycji demokratycznej. Był sygnatariuszem i inicjatorem wielu listów protestacyjnych. Publikował w wydawnictwach niezależnych, był współtwórcą niezależnego kwartalnika literackiego „Zapis” i jego redaktorem naczelnym, wykładowcą Uniwersytetu Latającego, współpracownikiem KOR-u. Za swoją działalność był poddawany rozmaitym represjom i szykanom, został objęty całkowitym zakazem druku. W stanie wojennym internowany.

\footnotetext{
${ }^{38}$ Wiersz opublikowany w tomie Ostatni raz, a5, Poznań 1995.

39 Wpis z 11.08.2020, https://jacekbochenski.home.blog/category/blog-iii/ (23.08.2020).
} 